AperTO - Archivio Istituzionale Open Access dell'Università di Torino

Female Employment and Elderly Care: the Role of Care Policies and Culture in 21 European Countries

This is a pre print version of the following article:

Original Citation:

Availability:

This version is available http://hdl.handle.net/2318/1559499

since 2021-03-15T14:57:26Z

Terms of use:

Open Access

Anyone can freely access the full text of works made available as "Open Access". Works made available under a Creative Commons license can be used according to the terms and conditions of said license. Use of all other works requires consent of the right holder (author or publisher) if not exempted from copyright protection by the applicable law. 


\title{
Female employment and elderly care: the role of care policies and culture in 21 European Countries
}

\author{
Naldini Manuela, Pavolini Emmanuele, Solera Cristina
}

\begin{abstract}
To what extent and in what ways do welfare state policies and cultural values in terms of intergenerational responsibilities affect the employment of mid-life women with care responsibilities toward a frail parent? The study draws on Eurobarometer micro-data, which have been integrated with country-level datasets. By means of a multilevel analysis across 21 European countries it analyses macro factors that influence the decisions of mid-life women to give up or reduce paid work when having to care for a frail elderly parent. The results show that, while the overall level of expenditure on LTC is not influential, living in a context with a high provision of formal care services and weak norms with regard to intergenerational obligations has positive effects on women's attachment to the labour market. Policies and cultural features also influence the extent to which women are polarised: in more defamilialised. countries, regardless of their level of education, female carers rarely reduce their level of employment.
\end{abstract}

Keywords

Elderly care, intergenerational obligations, welfare policies, women's employment, work-family reconciliation

\section{1- Introduction}

Combining paid work and family life can be viewed as a key issue in contemporary European societies, in terms of productivity, reproduction and gender-related social equality. Attention devoted to work-family reconciliation issues traditionally regards child care and how it affects mothers' employment (Stier and Epstein, 2001; Vlasbom and Shippers, 2006; Misra et al., 2007; Boeckmann et al 2015). Much less frequently, research on work-family reconciliation addresses the effect on employment of having to care for a dependent elderly parent (see among others Kroger and Yeandle 2013). Yet, given the triple phenomena of women's increasing participation in the workforce, increased life expectancy, and new laws raising retirement age, the issue of how informal elderly care affects women's employment becomes crucial in a context that increasingly tends to rely on informal care (family care).

Unlike the case of mothers, the existing literature on midlife women with frail elderly parents shows that caregiving does not have a major effect on their employment (Wolf and Soldo, 1994; Da Roit and Naldini, 2010), and, if it does, the effect is more in terms of reduced working hours (Pavalko and Artis 1997; Spiess and Schneider, 2003) than complete withdrawal from the workforce (Moen et al., 1994). The situation has more of an effect on a number of specific groups: those who lack adequate financial resources (Sarasa and Billingsley, 2008), and those for whom welfare support is not available or affordable (Lechner and Neal, 1999; Sarasa, 2008; Saraceno, 2010), if the care in question is for a co-resident dependent relative (Corti et al., 1994; Heitmueller and Michaud, 2006) and is particularly intensive (Lechner and Neal, 1999; Crespo, 2007).

As is the case for mothers' employment, the context in which women and families live plays a role in shaping their care strategies, and consequent labour market participation, when a parent is frail. Spiess and Schneider (2003) find that employment status or other work-related factors do not account for why mid-life women become caregivers, whereas they are significant when it comes to explaining why women who are already caregivers increase their hours of care. This association also holds in the opposite direction: the negative impact of care on employment is evident only when women start caring, not when they increase their caregiving activities. Moreover, controlling for individual and family characteristics, cross-country differences relate more to the diffusion of the " $x$ " than in its effects on the " $y$ ": high-intensity caregiving is much rarer in Scandinavian countries and more widespread in Southern Europe, where institutional care and 
home help services are less developed. Crespo (2007) reaches similar conclusions: intensive informal care for an elderly parent decreases the probability of participating in the labour market in both Northern and Southern countries. Yet, while in Northern countries a small percentage of women report that they provide intensive informal care to an elderly parent, in Southern Europe many women do so, with the consequence of an overall lower level of female involvement in the labour market.

Kotsadam (2011) shows that, when the issue of endogeneity in the work-care relationship is addressed, not only does the amount of informal elderly care differ across countries, but its effects on women's employment also differ. Informal caregiving for the elderly is indeed more negatively associated with women's employment opportunities and working hours in Southern European countries than in Nordic ones, with Central European countries in between. Higher quality, more freely available formal care, which represents a valid alternative to informal care, and less coercitive gendered-care norms, which further boost free choice in caregiving, are important macro level factors that explain why the effect on work of being a caregiver is not significant in Nordic welfare states.

In line with these studies, the article uses Eurobarometer micro-data on cross-country differences to explore the link between informal elderly care and labour market participation for midlife women, aged 4060. It presents three specificities. First, it compares a large number of countries including not only South, Central and Nordic Europe, but also East-Central Europe. Second, by means of multilevel analysis and by integrating micro-data with country-level indicators, it explicitly explores the role that macro-level factors play in mediating the effects of informal caregiving on employment. Third, it focuses on both policies and culture, and the inclusion of attitudinal items means it pays particular attention to norms, not only with regard to gender roles but also, and principally, with regard to intergenerational obligations.

The next section discusses literature on the role of the institutional and cultural context, and suggests some hypotheses. Section three describes the data, variables and methods used. Section four presents multilevel regression analyses. The final section summarises and discusses the main findings and implications.

\section{2- The role of the institutional and cultural context: care policies and (intergenerational) family care culture}

The institutional context plays a crucial role in shaping the extent to which and the way in which women combine work with caring for a frail elderly parent. In line with the 'regime' approach of Esping-Andersen (1990) and Antonnen and colleagues (Antonnen and Sipila, 1996; Antonnen et al., 2003), the institutional context can be defined as the combination of the labour market, the welfare state and the family, while, more specifically, the social care regime is the different "welfare mix" that provides care services for the elderly and the young at the intersection between formal and informal care, i.e., the family, the state, the non-profit sector and the market.

The division of responsibilities among the various institutions of the different "social care regimes", but especially between the state and the family, fosters different degrees of defamilialisation or familialism, that affect women's employment opportunities and options. Following Saraceno (2010; Saraceno and Keck, 2010) and paying attention to both (implicit and explicit) gender and intergenerational expectations within policies, three main patterns can be identified: 1) Familialism by default, or unsupported familialism, when the responsibility for providing care is assigned mainly to the family (women), because there are neither publicly provided alternatives to the family nor explicit financial provisions for family care; 2) Supported familialism, when the family is supported with parental leave, payments for care, or tax relief; 3) Defamilialisation, when there is a high level of services for the frail elderly (publicly-financed services and/or market provision) and the individualisation of social rights reduces family responsibility (along gender and generational lines).

Empirical evidence shows that, along the familialism/ defamilialisation continuum, these different types of policies have different impacts on women's employment. When the state, through social policies, provides a stand-in for familial (female) informal care, typically through affordable and high-quality care services, women's employment is encouraged. On the other hand, states which mainly support 'cash for care' policies (Ungerson and Yeandle, 2007; Pfau-Effinger, 2005), without introducing strict regulations on the use of these benefits, tend to assign the main care responsibilities to the family, thus inhibiting women's labourmarket participation (Da Roit and Le Bihan, 2010). This leads us to formulate the following four hypotheses: 
H1 Formal service coverage. A well-developed formal service sector, that is, a higher level of service coverage, and higher levels of public expenditure for elderly care (which is usually correlated to high levels of service), encourage mid-life women not to reduce their labour market participation in the presence of a frail elderly parent, because formal service provision leads to defamilialisation.

H2 Direct payment and care allowances. A higher level of LTC cash benefits is not expected to have any impact on midlife women's employment, because the negative impact of countries in which alternatives to family care are not offered, thus forcing re-familialisation, is cancelled out by the positive impact of countries in which financial provisions are bounded to buy care out of the family and thus pushing towards defamilialisation.

Policies that allow a close relative in paid employment to take 'time off to care', whether paid time, as in Italy (3 days per month), or unpaid time, as in Portugal (Knijn et al., 2013), thus assigning the family the role of main care 'agency', seem to have ambiguous effects on women's employment. As research on maternity and parental leave shows, leave is associated with an increase in women's employment in the short term, but, especially if long, it can lead to a reduction in relative pay and the quality of their jobs in the long run (Morgan and Zippel 2003; Boeckmann et al. 2015).

Institutions, through policies, not only define the opportunities and constraints of the setting in which women and couples act, but also contribute to determining the accepted standards and locus of care and accepted types of care-givers (Millar and Warman, 1996; Daly and Lewis, 1998; Naldini 2003). Indeed policies and cultures are strongly interdependent. A care culture that is family-oriented, on both the societal and individual levels, might, for instance, inhibit public provision of defamilialising care policies. The resulting policies would therefore make it more difficult to offer out-of-family forms of care to the frail elderly not only 'behaviourally', as a reasonable level of affordable care is not available, but also 'culturally', reinforcing the legitimation of family-oriented care cultures and practices (Pfau-Effinger, 2005; Szinovacz and Davey, 2008).

Although strongly intertwined, policies and culture do not overlap. As argued by Da Roit and Sabatinelli (2013), similar cultural orientations can translate into different eldercare policies, whose design is also affected by the level of need, financial constraints, the degree of fragmentation and the conflicts between the different actors involved. Moreover, definitions of gender roles and intergenerational solidarity are not only embedded in institutions, but they are also "formed" in everyday discourse and practices on a micro level (West and Zimmerman, 1987). Due to gender norms and practices, women are more likely to build a 'moral career' as carers (Finch and Mason, 1993), especially if there are no alternative forms of care on offer, while in terms of intergenerational care and support, children, and especially mid-life daughters, feel stronger normative obligations to act as carers in countries with a family culture which places high importance on intergenerational solidarity.

If we use the expression family and care culture (Pfau-Effinger, 2005; 2010) to describe the social norms on who should care for a family member, when and how women should work, and intergenerational obligations, the following hypothesis can be formulated:

H3 Family care culture. Higher degrees of family care/intergenerational care culture and higher degrees of familialism by default (unsupported), where the obligations (gender and intergenerational) to care are stronger, and there are fewer alternatives to family care, correlate with a higher likelihood that care-givers (daughters) will reduce their labour market participation.

As various studies have argued, the impact of the macro institutional and cultural context is not constant across individuals, being mediated by their own symbolic and material resources (Steiber and Hass, 2012) and the resources of those with whom they have "linked lives" (Elder, 1995). Education in particular seems to play a crucial role. Whether it is a question of different attitudes or a different level of income and status in the labour market, women's education consistently determines their involvement, or otherwise, in paid and unpaid work. However this gap is higher in familialistic contexts, where affordable public alternatives to infamily care are scarcer and gender and intergenerational obligations are stronger (Geist, 2005; Solera and Bettio, 2013).

H4 Education. The more familialistic the care culture and the less developed the care services, the stronger the effect of education on women's labour market participation when they have a frail elderly parent in need of care. 


\section{1-The Eurobarometer survey and the dependent variable}

In 2007 Eurobarometer produced a questionnaire investigating the issue of health and long-term care. Although relatively old, this dataset has the advantage of containing information on all EU countries, and not only on labour-market positions and care responsibilities and activities, but also on attitudes regarding the 'right' place and way to care for a frail elder, especially when it comes to intergenerational obligations. Given the focus of the research, the analysis was restricted to women aged 40-60 years old, in paid work or who had worked in the past, having or having had frail elderly parents in the last 10 years.

In order to photograph midlife women's employment behaviour in the context of elderly care, interviewees were asked the Eurobarometer question: "Did you give up paid work in order to take care of your elderly parents?" and the possible answers were: a) no; b) yes, they had to switch from full-time to parttime work; c) yes, they had to quit work completely. Table 1 presents the distribution of our dependent variable. If, following Kotsadam (2011), countries are grouped according to geographical locations, in all five groups a relatively small number of working women gave up their jobs or shifted to part-time work for care reasons: around $11 \%$ of women with frail parents made this choice; and in around half of the cases this meant not leaving the labour market but, instead, shifting to part-time work. This finding is in line with previous studies mentioned in the introduction: mid-life caregiving does not have a major effect on employment. However, interesting differences across countries emerge. In Scandinavian and Continental countries it is rarer for women to give up/reduce work for elderly care and, when it happens, it more often means a shift to part-time work rather than total withdrawal. In Anglo-Saxon, Mediterranean and EasternCentral European countries, there is a higher share of women changing their labour market participation. As for mothers, the mechanisms behind, and the consequences of switching to part-time work instead of completely quitting the labour market are clearly different (Stier and Lewin-Epstein 2001; Gash 2008). Yet, as the second part of table 1 shows, the sample sizes do not allow us to make this distinction. Thus, in regression analyses, the dependent variable was transformed into a dummy: a) did not give up work; b) gave up work (partially or totally).

\section{Table 1 here}

\subsection{The independent variables}

In order to explore the factors that influence midlife caregivers' labour market behaviour, two types of independent variables are considered: 'macro' country-level variables and 'micro' variables related to individuals and their families. Among both 'macro' and 'micro' variables a distinction was made between items pertaining to attitudes and type of care, and items referring to family, labour market and economic conditions, used as controls.

\section{Country-level care policies and culture variables}

In line with the concepts and arguments outlined in the theoretical section, four crucial 'macro' variables were used. The first three were institutional country-level variables aimed at capturing the level and type of public investment in long-term care (LTC) for the elderly around 2007, the year of the Eurobarometer survey. The variable 'expenditure on care for the elderly (as a percentage of GDP)' is provided by Eurostat and offers an overall picture of how different welfare systems tackle elderly care. However, this variable does not provide insights into the type of policies implemented. The variable 'level of service coverage', from the Multilinks database, was introduced to capture policies regarding services, which are considered in the literature as clearly defamilialising. This was calculated by adding the percentage of over-65s receiving home care to the percentage of those in residential homes. The role of cash allowances was calculated as a 
percentage of total public spending on LTC $^{1}$. Finally, a fourth country-level variable measured the degree of 'familialistic care culture'. This variable was obtained by means of a Principal Components Analysis based on four items (expressed in terms of the percentage of individuals in each country agreeing with them) available in the Eurobarometer survey: 'The frail elderly should live with their children or be regularly visited by them as the best option for an elderly parent living alone and in need of regular help'; 'Children should pay for the care of their parents if their parents' income is not sufficient'; 'Care should be provided by close relatives of the dependent person, even if this means that they have to sacrifice their careers to some extent'; 'The preferred way to obtain assistance if one becomes dependent and needs regular help and LTC is to be cared for by a relative at home'. The first component extracted accounted for more than $80 \%$ of the total variance. Negative values mean a low level of 'familialistic care culture', whereas positive ones indicate the opposite. Table 2 reports the distribution of the various macro variables.

\section{Table 2 here}

\section{Country-level control variables}

The cultural system is strongly interrelated not only with care policies but also with the social structure and the institutional system in general: policy or culture alone, though crucial, cannot determine behaviours or practices. The overall level of affluence of a country, its labour market opportunities and regulations, and regulations in other social policy areas might also shape women's labour supply (Steiber and Hass 2012; Boeckmann et al. 2015).

In order to control the robustness of the effects of the four macro variables described above, other macro country-level variables were used, calculated as the average value across 1997-2007, the same time span of the dependent variable. The 'real GNP at the per capita level' (in terms of purchasing power parity) was used as a proxy for the economic development level of the country. The 'total unemployment rate' was chosen in order to capture the overall functioning of the labour market and potential job opportunities. Lastly, the 'incidence of part-time employment on total employment' and the 'age of access to early retirement pensions', refer to constraints and opportunities that can influence why women with frail elderly parents might declare that they did not have to give up work or reduce it, due to having the option of early retirement or having already opted for a part-time job earlier in their lives, typically around motherhood.

\section{Individual- and household- level control variables}

In order to capture the effect of cultural and policy factors, relevant individual- and family-level factors also have to be controlled for. Thus we included: age; education; occupational class $^{2}$; the presence of a partner (both de facto or legally married) and at least one child under 16. More specific micro-level variables were added to measure the type of care provided: a dummy variable asking if the carer lived together with the parent being cared for ${ }^{3}$ and another variable measuring the intensity of informal care provided by the interviewed carer $^{4}$. These two variables were matched against four types of caregivers: daughters cohabiting with the frail parent, but providing a low level of care; cohabiting, providing intense care; not cohabiting and providing a low level of care; not cohabiting but providing intense care. One additional individual variable was cultural, intended to capture women's attitudes towards intergenerational care obligations. This variable was called 'individual familialistic care culture', and it was obtained through a Principal Components

1 In order to capture the effect of cash allowances on women's employment reduction, a measure of their eligibility criteria and generosity (for example of percentage of wages or in PPP), instead of their share in the composition of LTC expenditure, would have been better. Yet, reliable cross-country comparative data on levels of cash benefits are not available.

2

Education was measured in three levels: up to lower secondary; upper-secondary; tertiary. The occupational class was obtained by classifying occupations in four groups: bourgeoisie (managers, business owners, professionals); middle class (e.g. teachers, technicians); petty bourgeoisie (e.g. shop owners, craftsmen); working class (skilled and unskilled manual workers).

3 Co-resident caregivers were considered those who lived in the same house or, as stated in the Eurobarometer questionnaire, 'in a house next door'.

In absence of exact figures for hours of care per week or frequency of care (on a daily, weekly or monthly basis) as present in other datasets (Kotsadam 2011; Spiess and Schneider 2002; Crespo 2006), intensity was measured through the number of care activities (e.g. from doing the shopping to cooking, etc.) declared by the informal carer. More precisely, low intensity caregivers were those that declared to provide from 0 to 5 activities; high intensity caregivers were those providing from 6 to 11 activities. 
Analysis based on the same four items expressed in terms of a Likert scale that were used for 'general familialistic care culture', the country-level cultural variable described above.

\subsection{The issue of endogeneity}

The work-care relationship is a potentially endogenous relationship: on the one hand, caregivers might selfselect from a pool of underemployed or inactive people; on the other hand, some type of women might be more active than others, engaged in both caregiving and paid work. In both cases there are unobserved characteristics which affect both the opportunity to provide care and to be in paid employment, meaning that the employment-related differences between caregivers and non-caregivers are only partially accounted for by the fact of providing care. Yet, evidence on the importance of endogeneity is mixed. Using simultaneous equations, Crespo (2006) finds that the effect of informal caregiving on employment is underestimated if endogeneity is not controlled for, signalling the high likelihood that women both work and provide elder care. By contrast, through an instrumental-variable approach, Bolin et al (2008), argue that, once education, age and bad health are controlled for, unobserved heterogeneity and/or reverse causality is unlikely to drive the care/work results. Carmichael et al (2005) find that endogeneity is important for men and not for women, who in "cultural" terms have less freedom of choice when it comes to caregiving. Similarly, by applying fixed-effects estimators to panel data, Heitmuller (2007) points out that the existence of an endogeneity bias depends on the degree of freedom inherent in care decisions: it does not appear for high-intensity or coresidential caregivers, whereas it emerges for extraresidential, low-intensity caregivers. According to Kotsadam (2011), the same type of argument can be applied to cross-country comparisons. Where institutional support for elderly care is strong and gendered-care norms are weak, the endogeneity problem is more pronounced. In more coercive contexts, such as Southern or Eastern-Central European countries, the effect of unobserved characteristics should be lower or inexistent.

Following Heitmueller (2007), Carmichael et al (2005) and Kotsadam (2011), it can be argued that differences in unobserved heterogeneity can be interpreted as stemming from differences in opportunities for choice.

Yet, unlike in these studies, we did not statistically control for endogeneity for several reasons. Firstly, because of the data used, the causal link between work and care is embedded in the dependent variable: since people were asked whether or not they had to reduce their labour supply due to caring responsibilities towards a frail parent, estimations referred not to the effect that being a carer had on employment, but that of macro institutional and cultural factors on carers. Secondly, among the controls for individual and family features, information was included on what is usually considered the crucial unobserved characteristic, that is, attitudes. Having a measure of attitudes was also crucial to "test" the "degree of choice" argument: if the significance of attitudes depends on the significance of the constraints, we should therefore observe, ceteris paribus, that attitudes only have significant effects on women's labour supply in low-coercitive contexts; moreover, if intensity of care is part of the care and reconciliation strategy that mid-life women deploy with regard to a different set of preferences and constraints, in low-coercitive contexts there should also be a stronger effect on the type of care. By running multilevel models with cross-level interactions between the country's level of familialistic care culture or service coverage with women's own attitudes or intensity of care, the article found support for this: the more formal care is provided and the less norms support intergenerational solidarity, the more attitudes and intensity of care have an effect on the likelihood that women will reduce their labour market participation when they have a frail parent to look after. In other words, it is only in weak coercitive contexts, where intense care is not a "given", because there are more formal alternatives to family care and because women's 'moral careers' are less constructed around family care, that women are allowed to follow their preferences, and those who choose to be intensive carers are a very select group. By controlling for attitudes regarding the 'right' place and way to care for a frail elder, this selectivity is largely captured in the present article and thus there is much less scope for an endogeneity bias.

\section{4- Reducing labour-market participation when caring for a frail parent: findings}

\subsection{The influence of care policies and family care culture}


In order to capture the micro and macro determinants of middle-aged women's labour-market participation, a series of two-level logistic regressions was estimated. One major advantage of multilevel models, compared to conventional regression models, is that they recognize the existence of variation in the outcome at both the individual and the macro level. More precisely, the analysis included 4631 women (level 1) grouped into 21 countries (level 2), and it modelled the probability that a woman aged 40-60 with working experience and a frail parent either switches to part-time or quits completely. The log odds of binary choices were posited as a function of the 12 individual and family characteristics outlined(level 1) and the four country-level characteristics (level 2). In particular, random intercept models were used in order to show that, after controlling for relevant micro level variables, the macro context continues to influence women's labourmarket behaviours.

Following Van der Lippe et al. (2011), different sets of multilevel models were estimated. First, all individual- and family-level characteristics and the geographical country-group variable were included (model 1). Then, in order to test the first three hypotheses, the country-group variable was substituted with the four crucial macro level indicators, first by introducing them singly (models 2 to 5), then all together (model 6) ${ }^{5}$. Finally, hypothesis four on the interaction between the effect of women's level of education and country level of familialistic care culture or service coverage was tested (model 7 and 8).

The type of country in which women live appears to influence their labour-market decisions in relation to elderly care responsibilities (table 3). Controlling for individual characteristics, two groups emerge: Scandinavian and Continental countries are those with the lowest likelihood of reducing labourmarket participation, followed by Anglo-Saxon, Mediterranean and Eastern-Central European countries.

When unpacking the macro context into policies and cultural influences, only two indicators have a significant influence. More precisely, and as expected, the more the country shows a familialistic culture, the more mid-life women tend to reduce labour-market participation around caregiving. Moreover, the more the state provides support for elderly care, through home care or residential homes, the less women disinvest from the labour market. One the other hand, the overall level of social expenditure on LTC does not appear to be influential. Evidently, although high levels of public expenditure usually correlate with high levels of service, these two indicators do not represent the same thing: while the first does not tell us anything about the way money is spent, therefore about the capacity to defamilialise, the second does, with clear positive effects on women's labour market attachment, as expected. Moreover, ceteris paribus, cash benefits do not appear to be influential. Although caution is required, given the limits of the type of measure proposed, this is in line with hypothesis 2.

As much research on mothers' employment and the gender division of unpaid work around parenthood shows (Geist 2005; Van der Lippe et al. 2011, Boeckmann et al 2015), the macro context affects also the level and type of polarization among women and families with different sets of resources. Models 7 and 8 confirm hypothesis 4 , namely that in the case of midlife caregivers, highly and poorly educated women behave more similarly in contexts with a high provision of LTC services and low coercitive intergenerational norms.

Table 3 here

\subsection{Robustness checks}

Although important, policies and culture alone cannot fully determine midlife women's combination of employment and elderly care. Following Boeckmann et al (2015), in table 4 other macro indicators were introduced as controls in order to test whether the effect of our crucial macro variables related to care policies and culture remains robust. First, all macro controls were entered alone (model 9), then singly, together with all the crucial macro variables (models 10 to 13). Finally, in order not to reduce degrees of freedom, we kept only the crucial macro variable significant (service coverage) and its effect was tested controlling for all four macro controls (model 14).

Findings show that, among other institutional and structural factors, only the quota of part-time employment significantly shapes the labour market behavior of midlife female caregivers. The level of affluence of a country, the level of labour market opportunities and regulations regarding retirement age are not influential. In more specific terms, the higher the quota of part-time work in the labour market, the less

$5 \quad$ Macro care culture was excluded because of its high correlation with service coverage (-0.9), which can be seen as empirical evidence that care policies and culture are strongly intertwined. 
midlife women with caring responsibilities toward a frail parent leave paid work or move to part-time. This is because countries with a high proportion of part-timers are those where part-time work represents the main reconciliation strategy that women and families adopt when becoming parents. Then later on, either because on a practical level they have time for care, or symbolically they have built their moral careers as carers, it is likely that these women will take care of their frail parent without changing their labour market participation, having already left paid work or moved to part-time around motherhood.

\section{Table 4 here}

\section{5- Conclusions}

By using Eurobarometer microdata, which also include information on attitudes, and by integrating them with country-level measures, this article uses multilevel analysis across 21 countries and investigates to what extent and in what ways welfare state policies and family care culture affect the employment of midlife women with a frail parent in need of care. Results show that living in a setting such as Scandinavia, with well-developed formal care services and weak norms regarding intergenerational obligations, has a positive effect on women's attachment to the labour market. Conversely, living in a setting where the state's dominant policy approach combines 'familialism by default' with 'supported familialism', and where intergenerational care obligations are higher, such as in Southern and Eastern-Central European countries, daughters (mid-life women) with family responsibilities encounter more difficulties when it comes to remaining in the labour market. By contrast, ceteris paribus, the overall level of expenditure on LTC and how this breaks down in terms of cash benefits is not influential, signalling that what matters is not the "effort" but the "approach": adopting a LTC policy system based more on "cash for care" than services could encourage more carers to give up work, by providing an alternative source of funding for the carer, especially in those countries in which financial provisions are not bounded to buy out-of-home care and there is thus a push towards re-familialisation. The article shows that levels of service provision and familyoriented care cultures also influence the extent to which women are polarised: in more defamilialised countries, regardless of their level of education, women rarely reduce their labour supply when carers of a frail parent.

As well argued by gender-sensitive scholars, policies and culture are strongly intertwined and consist of a complex "package" of dimensions, whose individual effects on choices over the life course depend on the effect of, and interaction with, the others. In order to reach conclusions on the role played by the context, longitudinal data on both the objective and subjective dimensions of life courses, and more complete crosscountry, time-series data on the overall institutional package, and its interplay with the cultural dimension, need to be collected. Future research should focus on this.

\section{References}

Anttonen A., Sipilä J. (1996) European social care services: Is it possible to identify models? Journal of European Social Policy 6(2): 87-100.

Anttonen A., Baldock J. and Sipilä J. (2003) The Young, the Old and the State. Social Care Systems in Five Industrial Nations. Cheltenham: Edward Elgar.

Boeckmann I., Misra, J. and Budig M. (2015) Cultural and Institutional Factors Shaping Mothers' Employment and Working Hours in Postindustrial Countries. Social Forces, 93 (4): 1301-1333.

Bolin K., Bjorn L. and Lundborg P. (2008) Your next of kin or Your own career? Caring and Working among the 50+ of Europe. Journal of Health Economics, 27: 718-738.

Carmichael F., Connell G., Hulme C. and Sheppard, S. (2005), Who Cares and at What Cost? The Incidence and the Opportunity Costs of Informal Care, Salford University, Management \& Management Science Research Institute Working Paper 209/05.

Corti L., Laurie H. and Dex S. (1994) Caring and Employment. Colchester: University of Essex.

Crespo L. (2007) Caring for Parents and Employment Status of European Mid-Life Women. Madrid: Centro de Estudios Monetarios y Financieros (CEMFI). 
Da Roit B., Le Bihan B. (2010) Similar and yet so different: cash-for-care in six European countries' long-term care policies. Milbank Quarterly 88(3): 286-309.

Da Roit B., Naldini M. (2010) Should I stay or should I go? Combining work and care for an older parent in Italy. South European Society \& Politics 15(4): 531-551.

Da Roit B., Sabatinelli, S. (2013) Nothing on the Move or Just Going Private? Understanding the Freeze on Child- and Eldercare Policies and the Development of Care Markets in Italy. Social Politics, 20(3):430-453.

Daly M., Lewis J. (1998) Introduction: Conceptualising social care in the context of Welfare State restructuring. In: Lewis J. (ed.) Gender, Social Care and Welfare State Restructuring in Europe. Aldershot: Ashgate, 86-103.

Elder G. (1995) The life course paradigm: social change and individual development. In: (eds.), Moen P., Elder G. and Lusher K. Examining Lives in Context: Perspective on the Ecology of Human Development. Washington, American Psychological Association, pp. 101-139.

Esping-Andersen G. (1990) The Three Worlds of Welfare Capitalism. New York: Polity Press.

European Commission (2012) The 2012 Aging Report, Brussels: European Commission.

Finch J., Mason J. (1993) Negotiating Family Responsibilities. London: Routledge.

Gash V. (2008) Preference or constraint? Part-time workers' transitions in Denmark, France and the United Kingdom. Work Employment \& Society, 22 (4): 655-674.

Geist C. (2005) The welfare state and the home: Regime differences in the domestic division of labour. European Sociological Review 21: 23-41.

Heitmueller A. (2007) The Chicken or the Egg? Endogeneity in Labour Market Participation of Informal Carers in England. Journal of Health Economics, 26(3): 536-559.

Heitmueller A., Michaud P. (2006) Informal Care and Employment in England: Evidence from the British Household Panel Survey IZA Discussion Paper 2010. Bonn: IZA.

Knijn T., Martin C. and Le Bihan B. (2013) Workers under pressure and social care arrangements: A research framework. In: Le Bihan B., Martin C. and Knijn T. (eds.) Work and Care under Pressure. Care Arrangements across Europe. Amsterdam: Amsterdam University Press, 7-31.

Kotsadam A. (2011) Does informal eldercare impede women's employment? The case of European Welfare States. Feminist Economics, 17(2): 121-144.

Kroger T., Yeandle S. (2013) Reconciling work and care: an international analysis, in: Kroger T., Yeandle S. (eds.), Combining paid work and family care. Policies and experiences in international perspective. Bristol: Policy Press, pp. 3-21.

Lechner V., Neal M. (eds.) (1999) Working and Caring for the Elderly. International Perspective. Philadelphia: Taylor and Francis.

Millar J., Warman A. (1996) Family Obligations in Europe. London: Family Policy Studies Centre.

Misra J., Budig M.J. and Moller S. (2007) Reconciliation policies and the effects of motherhood on employment, earnings and poverty. Journal of Comparative Policy Analysis: Research and Practice 9(2): 135-155.

Moen P., Robison J. and Fields V. (1994) Women's work and caregiving roles: A life-course approach. Journal of Gerontology: Social Sciences 49(4): 176-186.

Morgan K.J. and Zippel K. (2003). Paid to Care: The Origins and Effects of Care Leave Policies in Western Europe. Social Politics 10 (1): 49-85

Naldini M. (2003) The Family in Mediterranean Welfare States, London/New York, Frank Cass.

Pavalko E.K., Artis J.E. (1997) Women's caregiving and paid work: causal relationships in late midlife. Journal of Gerontology: Social Sciences 52(4): 170-179.

Pfau-Effinger B. (2005) Welfare state policies and the development of care arrangements. European Societies 7(3): 321-341.

Pfau-Effinger B. (2010) Cultural and Institutional Contexts. In: Treas J., Drobnic S. (eds.) Dividing the Domestic. Men, Women, \& Household Work in Cross-National Perspective. Stanford: Stanford University Press, 125-146.

Saraceno C., Keck W. (2010) Can we identify intergenerational policy regimes. European Societies 12(5): 675-696.

Saraceno C. (2010) Social inequalities in facing old-age dependency: a bi-generational perspective. Journal of European Social Policy 20(1): 32-44.

Sarasa S. (2008) Do welfare benefits affect women's choices of adult caregiving. European Sociological Review 24(1): 37-51.

Sarasa S., Billingsley S. (2008) Personal and household caregiving from adult children to parents and social stratification. In: Saraceno C. (ed.) Families, Ageing and Social Policy. Intergenerational Solidarity in European Welfare States. Cheltenham: Edward Elgar, 123-146.

Solera C., Bettio F. (2013) Women's Continuous Careers in Italy: The Education and Public Sector Divide. Population Review 52(1): 129-148.

Spiess C.K., Schneider U. (2003) Interactions between care-giving and paid work hours among European midlife women, 1994 to 1996. Ageing and Society 23(1): 41-68.

Steiber N., Haas B. (2012) State of the Art. Advances in Explaining Women's Employment Patterns. Socio-Economic Review 10(2): 343-367.

Stier H., Lewin-Epstein N. (2001) Welfare regimes, family-supportive policies, and women's employment along the life-course. American Journal of Sociology 106(6): 1731-60. 
Szinovacz M., Davey A. (eds.) (2008) Caregiving Contexts, Cultural, Familial and Societal Implications. New York: Springer.

Ungerson C., Yeandle S. (2007) Conclusion: dilemmas, contradiction and changes. In: Ungerson C., Yeandle S. (eds.) Cash for Care in Developed Welfare State. Palgrave Macmillan, 187-206.

Van der Lippe T., de Ruijter J., de Ruijter E. et al. (2011) Persistent inequalities in time use between men and women: A detailed look at the influence of economic circumstances, policies, and culture. European Sociological Review 27(2): 164-179.

Vlasbom J., Shippers J. (2006) Changing dynamics in female employment around childbirth: evidence from Germany, the Netherlands and the UK. Work, Employment and Society 20(2): 329-347.

West C., Zimmerman D. (1987) Doing Gender. Gender\&Society 1(2): 125-151.

Williams F. (2012) Converging variations in migrant care work in Europe. Journal of European Social Policy 22(4): 363-373.

Wolf D.A., Soldo B.J. (1994) Married women's allocation of time to employment and care of elderly parents. Journal of Human Resources 29(4): 1259-1276. 
Table 1. Mid-life working women and the decision to reduce labour-market participation for elderly care, by country

\begin{tabular}{|c|c|c|c|c|c|c|}
\hline & \multicolumn{2}{|c|}{ Share } & \multicolumn{4}{|c|}{$N$} \\
\hline & $\begin{array}{c}\text { Share among carers } \\
\text { reducing LM } \\
\text { partecipation }\end{array}$ & $\begin{array}{l}\text { Share among those } \\
\text { reducing who move } \\
\text { to part-time }\end{array}$ & Not reducing & $\begin{array}{l}\text { Reducing to } \\
\text { part-time }\end{array}$ & $\begin{array}{l}\text { Giving up } \\
\text { work }\end{array}$ & Total N \\
\hline Scandinavian countries & 5.0 & 63.5 & 888 & 33 & 14 & 935 \\
\hline Denmark & 2.8 & 44.4 & 307 & 4 & 5 & 316 \\
\hline Sweden & 6.4 & 85.0 & 292 & 17 & 3 & 312 \\
\hline Finland & 5.8 & 66.6 & 289 & 12 & 6 & 307 \\
\hline Anglo-Saxon countries & 14.9 & 44.4 & 441 & 32 & 40 & 513 \\
\hline UK & 11.2 & 33.3 & 283 & 12 & 24 & 319 \\
\hline Ireland & 18.5 & 55.5 & 158 & 20 & 16 & 194 \\
\hline Continental countries & 8.2 & 57.8 & 1315 & 65 & 46 & 1426 \\
\hline Austria & 16.8 & 79.4 & 168 & 27 & 7 & 202 \\
\hline Germany & 9.2 & 43.7 & 317 & 14 & 18 & 349 \\
\hline Belgium & 4.7 & 57.1 & 280 & 8 & 6 & 294 \\
\hline France & 6.7 & 45.0 & 277 & 9 & 11 & 297 \\
\hline Netherlands & 3.8 & 63.6 & 273 & 7 & 4 & 284 \\
\hline Mediterranean countries & 13.3 & 56.8 & 898 & 68 & 65 & 1031 \\
\hline Spain & 17.3 & 41.6 & 229 & 20 & 28 & 277 \\
\hline Greece & 7.3 & 45.8 & 305 & 11 & 13 & 329 \\
\hline Italy & 13.8 & 75.5 & 205 & 19 & 14 & 238 \\
\hline Portugal & 14.9 & 64.2 & 159 & 18 & 10 & 187 \\
\hline Eastern-Central European c. & 14.5 & 56.9 & 1516 & 145 & 114 & 1775 \\
\hline Bulgaria & 12.6 & 55.1 & 201 & 16 & 13 & 230 \\
\hline Czech Republic & 15.1 & 53.5 & 241 & 23 & 20 & 284 \\
\hline Hungary & 17.9 & 58.2 & 197 & 25 & 18 & 240 \\
\hline Poland & 5.1 & 50.0 & 259 & 7 & 7 & 273 \\
\hline Romania & 17.1 & 54.8 & 150 & 17 & 14 & 181 \\
\hline Slovenia & 6.6 & 72.2 & 254 & 13 & 5 & 272 \\
\hline Slovakia & 27.4 & 54.3 & 214 & 44 & 37 & 295 \\
\hline Total & 11.0 & 55.1 & 5058 & 343 & 279 & 5680 \\
\hline
\end{tabular}

Notes: only women aged between 40 and 60 with a frail elderly parent in last 10 years, who are working or have worked (thus, at risk of being carers) Source: own elaboration on Eurobarometer (2007) 
Table 2. Differences among economic, institutional and cultural contexts, by country

\begin{tabular}{|c|c|c|c|c|c|c|c|c|}
\hline & Car & $\begin{array}{r}\text { policies an } \\
\text { (aroun }\end{array}$ & $\begin{array}{l}\text { culture varic } \\
\text { 2007) }\end{array}$ & & Econ & $\begin{array}{r}\text { mic and labol } \\
\text { (averages }\end{array}$ & $\begin{array}{l}\text { market fun } \\
997-2007)\end{array}$ & oning \\
\hline & $\begin{array}{c}\text { Country } \\
\text { familialistic } \\
\text { care culture }^{\mathrm{a}}\end{array}$ & $\begin{array}{c}\text { Service } \\
\text { coverage } \\
(\% \text { of over- } \\
65 \mathrm{~s} \\
\text { covered })^{b}\end{array}$ & $\begin{array}{l}\text { Expenditure } \\
\text { on care for } \\
\text { elderly (\% } \\
\text { of GDP) }\end{array}$ & 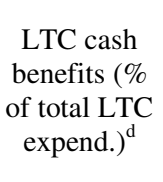 & $\begin{array}{c}\text { Real GNP, } \\
\text { PPP\$ per } \\
\text { capita }^{\mathrm{e}}\end{array}$ & $\begin{array}{c}\text { Total } \\
\text { unemploym } \\
\text { ent rate }(15- \\
64)^{\mathrm{f}}\end{array}$ & $\begin{array}{l}\text { Part-time } \\
\text { work (\% of } \\
\text { total } \\
\text { employ. } \\
15-64)^{\mathrm{f}}\end{array}$ & $\begin{array}{l}\text { Female } \\
\text { retirement } \\
(\text { age })^{\mathrm{g}}\end{array}$ \\
\hline Scandinavian countries & 14.6 & 19.1 & 1.6 & 8.8 & 33122 & 7.0 & 18.8 & 63.7 \\
\hline DK & 18.1 & 27.3 & 1.64 & 10.0 & 33926 & 4.7 & 21.4 & 65 \\
\hline SE & 7.2 & 16.4 & 2.40 & 4.1 & 33966 & 7.0 & 22.8 & 64 \\
\hline FI & 18.5 & 13.5 & 0.66 & 12.4 & 31474 & 9.4 & 12.3 & 62 \\
\hline Anglo-Saxon countries & 34.3 & 12.4 & 0.5 & 28.0 & 36191 & 5.4 & 20.3 & 62.5 \\
\hline UK & 34.3 & 15.2 & 0.77 & 28.0 & 32962 & 5.4 & 24.4 & 60 \\
\hline IE & 34.2 & 9.6 & 0.20 & 28.0 & 39420 & 5.3 & 16.2 & 65 \\
\hline Continental countries & 23.8 & 15.4 & 0.4 & 32.2 & 32900 & 7.1 & 23.7 & 61.2 \\
\hline AT & 30.7 & 20.3 & 0.95 & 51.9 & 34209 & 4.5 & 18.3 & 62 \\
\hline $\mathrm{BE}$ & 24.9 & 12.7 & 0.04 & 19.6 & 32645 & 8.1 & 19.6 & 60 \\
\hline NL & 12.2 & 19.8 & 0.72 & 41.9 & 35713 & 4.7 & 42.7 & 65 \\
\hline FR & 17.8 & 12.6 & 0.25 & 15.5 & 30103 & 9.0 & 16.9 & 56 \\
\hline $\mathrm{DE}$ & 33.6 & 11.4 & 0.18 & 32.1 & 31830 & 9.3 & 20.9 & 63 \\
\hline Mediterranean countries & 46.4 & 6.2 & 0.2 & 22.0 & 25979 & 9.5 & 8.0 & 56.8 \\
\hline ES & 43.7 & 6.3 & 0.25 & 17.5 & 28124 & 11.9 & 9.1 & 60 \\
\hline IT & 52.1 & 6.1 & 0.11 & 45.3 & 28964 & 8.9 & 9.8 & 57 \\
\hline PT & 45.3 & 11 & 0.20 & 0.0 & 21495 & 7.0 & 8.4 & 55 \\
\hline GR & 44.4 & 1.3 & 0.09 & 25.0 & 25332 & 10.3 & 4.7 & 55 \\
\hline Eastern-Central European c. & 54.5 & 3.0 & 0.2 & 45.6 & 15107 & 10.4 & 5.7 & 57.7 \\
\hline $\mathrm{HU}$ & 47.4 & 3.0 & 0.34 & 72.5 & 17266 & 6.9 & 3.7 & 58 \\
\hline PL & 67.5 & 3.3 & 0.24 & 52.9 & 14121 & 15.4 & 9.2 & 55 \\
\hline $\mathrm{RO}$ & 48 & 0.1 & 0.02 & 12.7 & 9917 & 7.2 & 11.3 & 58 \\
\hline SI & 44.6 & 5.7 & 0.22 & 37.9 & 16739 & 6.5 & 6.7 & 60 \\
\hline SK & 51.4 & 2.0 & 0.35 & 16.7 & 16739 & 16.4 & 2.3 & 58 \\
\hline BG & 60.8 & 0.8 & 0.02 & 60.0 & 10065 & 13.2 & 2.3 & 58 \\
\hline $\mathrm{CZ}$ & 61.5 & 6.2 & 0.38 & 66.3 & 20905 & 7.3 & 4.7 & 56.8 \\
\hline
\end{tabular}

Sources: ${ }^{a}$ percentage of the population declaring that care should be provided by close relatives even if it means they have to sacrifice careers; Eurobarometer (2007); ${ }^{\mathrm{b}}$ Multilink database (2012 version); ${ }^{\mathrm{c}}$ Eurostat - Social Protection online database; ${ }^{\mathrm{d}}$ European Commission $(2012)$; ${ }^{\mathrm{e}}$ Eurostat - Economy and Finance online database; ${ }^{\mathrm{f}}$ Eurostat LTS on line database; ${ }^{\mathrm{g}}$ in those countries where there is not an early retirement pension the data 
Table 3. Estimated coefficients of two-level Logistic Regression for (partially) giving up work for caring responsibilities for a frail parent (Random intercept models):

the role of policies and culture

$\begin{array}{ccccc}\text { M1 } & \text { M2 } & \text { M3 } & \text { M4 } & \text { M5 } \\ \text { Individual } & \text { Individual } & \text { Individual } & \text { Individual } & \text { Individual } \\ \text { variables }+ & \text { variables }+ & \text { variables }+ & \text { variables }+ & \text { variables }+ \\ \text { Macro } & \text { Macro care } & \text { Macro Service } & \text { Macro } & \text { Macro } \\ \text { geographical } & \text { culture } & \text { coverage } & \text { Expenditurefor } & \text { relevance of } \\ \text { groups } & & & \text { elderly } & \text { LTC cash } \\ & & & & \text { benefits }\end{array}$

\section{Level 1 (Women)}

Age over 50 (ref. 40-49 y.o.)

Education (ref. up to lower-secondary)

Upper-secondary

Tertiary

Class (ref. bourgeoisie)

Middle class

Petty bourgeoisie

Working class

Partner (ref. not in partnership)

Children $<16$ (ref. not present)

Individual Care Culture (pca)

Type of carers (ref. cohabiting, low intens.)

Cohabiting, high intensity

Not cohabiting, low intensity

Not cohabiting, high intensity

Level 2 (Countries)

Geographical groups (ref. Scandinavian)

Anglo-Saxon

Continental

Mediterranean

Eastern-Central Europe

Macro care policies and culture variables

Care culture (pca)

LTC services' coverage

Expenditure for elderly (as \% GDP)

The relevance of LTC cash benefits

(as \% of total public LTC expendit.)

Level $1 *$ Level 2 (cross-level interactions)

Macro care culture* women's education

(ref. up to lower-secondary)

*Upper-secondary

*Tertiary

Macro service coverage* women's

education (ref. up to lower-secondary)

*Upper-secondary

*Tertiary

\section{Constant}

Variance between countries

(se)

Log-likelihood

$\mathrm{N}$. of women

$\mathrm{N}$. of countries

-0.01
0.06
-0.04

$0.23^{*}$
$0.25^{*}$
0.10
$-0.15^{*}$
-0.02
$0.15^{* * *}$

$0.88^{* * *}$
$-0.38^{* *}$
$0.84^{* * *}$


$0.92^{* *}$
0.21
$0.75^{*}$
$0.65^{*}$

$-0.01$

$-0.01$

$-0.01$

$-0.01$

0.06

$-0.04$

$0.23 *$

$0.25^{*}$

0.10

$-0.15^{*}$

$-0.02$

$0.15^{* * *}$

$-0.02$

$0.15^{* * *}$

0.02

$0.15 * * *$

$0.88^{* * * *}$

$0.88 * * *$

$0.88 * * *$

$-0.38 * * *$

$-0.38 * * *$

$-0.38 * * *$

$0.84 * * *$

$0.84 * * *$
$0.21 *$

$-0.03 *$

$-0.16$

0.01

Notes: only women aged between 40 and 60 with a frail elderly parent in last 10 years, who are working or have worked

*** $\mathrm{p}<0.01 ; * * \mathrm{p}<0.05 ; * \mathrm{p}<0.10$

Source: own processing of Eurobarometer (2007)

Table 4. Estimated coefficients of two-level Logistic Regression for (partially) giving up work for caring responsibilities for a frail parent (Random intercept models):

robustness checks

$\begin{array}{ccccc}-2.76 * * * & -2.23 * * * & -1.95 * * * & -2.17 * * * & -2.27 * * * \\ 0.19 & 0.23 & 0.24 & 0.27 & 0.27 \\ (0.08) & (0.09) & (0.09) & (0.10) & (0.10) \\ -1498.1 & -1499.7 & -1499.8 & -1500.9 & -1501.2 \\ 4631 & 4631 & 4631 & 4631 & 4631 \\ 21 & 21 & 21 & 21 & 21\end{array}$




\begin{tabular}{|c|c|c|c|c|c|}
\hline & $\begin{array}{c}\text { M9 } \\
\text { Individual } \\
\text { variables }+ \\
\text { All Macro } \\
\text { controls }\end{array}$ & $\begin{array}{c}\text { M10 } \\
\text { Individual } \\
\text { variables }+ \\
\text { Macro crucial } \\
\text { variables }+ \\
\text { GNP }\end{array}$ & $\begin{array}{c}\text { M11 } \\
\text { Individual } \\
\text { variables }+ \\
\text { Macro crucial } \\
\text { variables }+ \\
\text { Parttime share }\end{array}$ & $\begin{array}{c}\text { M12 } \\
\text { Individual } \\
\text { variables + } \\
\text { Macro crucial } \\
\text { variables + } \\
\text { Unemploym. } \\
\text { rate } \\
\end{array}$ & $\begin{array}{c}\text { M13 } \\
\text { Individual } \\
\text { variables }+ \\
\text { Macro crucial } \\
\text { variables }+ \\
\text { Early } \\
\text { retirement }\end{array}$ \\
\hline \multicolumn{6}{|l|}{ Level 1 (Women) } \\
\hline Age over 50 (ref. $40-49$ y.o.) & -0.01 & -0.01 & -0.01 & -0.01 & -0.01 \\
\hline \multicolumn{6}{|l|}{ Education (ref. up to lower-secondary) } \\
\hline Upper-secondary & 0.06 & 0.06 & 0.06 & 0.06 & 0.06 \\
\hline Tertiary & -0.04 & -0.04 & -0.04 & -0.04 & -0.04 \\
\hline \multicolumn{6}{|l|}{ Class (ref. bourgeoisie) } \\
\hline Middle class & $0.23 *$ & $0.23 *$ & $0.23 *$ & $0.23 *$ & $0.23 *$ \\
\hline Petty bourgeoisie & $0.25^{*}$ & $0.25 *$ & $0.25^{*}$ & $0.25 *$ & $0.25 *$ \\
\hline Working class & 0.10 & 0.10 & 0.10 & 0.10 & 0.10 \\
\hline Partner (ref. not in partnership) & $-0.15^{*}$ & $-0.15^{*}$ & $-0.15^{*}$ & $-0.15^{*}$ & $-0.15^{*}$ \\
\hline Children $<16$ (ref. not present & -0.02 & -0.02 & -0.02 & -0.02 & -0.02 \\
\hline Individual Care Culture (pca) & $0.15 * * *$ & $0.15 * * *$ & $0.15 * * *$ & $0.15 * * *$ & $0.15 * * *$ \\
\hline \multicolumn{6}{|l|}{ Type of carers (ref. cohabiting, low intens.) } \\
\hline Cohabiting, high intensity & $0.88 * * *$ & $0.88 * * *$ & $0.88 * * *$ & $0.88 * * *$ & $0.88 * * *$ \\
\hline Not cohabiting, low intensity & $-0.38 * * *$ & $-0.38 * * *$ & $-0.38 * * *$ & $-0.38 * * *$ & $-0.38 * * *$ \\
\hline Not cohabiting, high intensity & $0.84 * * *$ & $0.84 * * *$ & $0.84 * * *$ & $0.84 * * *$ & $0.84 * * *$ \\
\hline \multicolumn{6}{|l|}{ Level 2 (Countries) } \\
\hline \multicolumn{6}{|l|}{ Macro care policies } \\
\hline LTC services' coverage & & $-0.06 * *$ & -0.02 & $-0.05 * *$ & $-0.05 * *$ \\
\hline Expenditure for elderly (as \% GDP) & & 0.22 & 0.12 & 0.18 & 0.12 \\
\hline $\begin{array}{l}\text { The relevance of LTC cash benefits } \\
\text { (as \% of total public LTC exp.) }\end{array}$ & & -0.00 & -0.00 & -0.00 & -0.00 \\
\hline \multicolumn{6}{|l|}{ Macro control variables } \\
\hline Real GNP, PPP\$ per capita & 0.00 & 0.00 & & & \\
\hline Part-time quota (as \% total female empl) & $-0.04 * *$ & & -0.02 & & \\
\hline Total unemployment rate (15-64) & -0.02 & & & -0.04 & \\
\hline Female early retirement (age) & 0.03 & & & & 0.03 \\
\hline Constant & $-3.71 *$ & $-2.34 * * *$ & $-1.82 * * *$ & $-1.32 * *$ & $-3.83 *$ \\
\hline $\begin{array}{l}\text { Variance between countries } \\
\text { (se) }\end{array}$ & $\begin{array}{c}0.20 \\
(0.08)\end{array}$ & $\begin{array}{c}0.22 \\
(0.08)\end{array}$ & $\begin{array}{c}0.22 \\
(0.09)\end{array}$ & $\begin{array}{c}0.22 \\
(0.09)\end{array}$ & $\begin{array}{c}0.22 \\
(0.09)\end{array}$ \\
\hline Log-likelihood & -1498.6 & -1499.1 & -1499.3 & -1499.2 & -1499.4 \\
\hline N. of women & 4631 & 4631 & 4631 & 4631 & 4631 \\
\hline N. of countries & 21 & 21 & 21 & 21 & 21 \\
\hline
\end{tabular}

